\title{
Examining Young Malaysians Travel Behaviour and Expenditure Patterns in Domestic Tourism
}

\author{
Lim Khong Chiu ${ }^{1}$, Kamal Izzuwan Ramli ${ }^{1}$, Noor Suhaila Yusof ${ }^{1} \&$ Cheah Swee Ting ${ }^{1}$ \\ ${ }^{1}$ School of Tourism, Hospitality and Environmental Management, Universiti Utara Malaysia, Sintok, Kedah \\ Correspondence: Lim Khong Chiu, School of Tourism, Hospitality and Environmental Management, Universiti \\ Utara Malaysia, Sintok, Kedah. E-mail: 1kc@uum.edu.my
}

Received: September 1, 2014

doi:10.5539/ass.v11n9p77
Accepted: September 26, 2014 Online Published: April 2, 2015

URL: http://dx.doi.org/10.5539/ass.v11n9p77

\begin{abstract}
Young travellers, though restricted by relatively low levels of disposable income, are commonly having high interest and leisure time in exploring new destinations. It has been found that young travellers have high expectations regarding the importance of value for money though they have their financial resources available for travelling. Therefore, it has raised questions on the worthiness of carrying out a study about the travel behaviour and expenditure patterns among the young travellers in Malaysia. The study employed a survey questionnaire to collect data, which was adapted from standardized measures. A total of 643 respondents, which has been randomly selected in the Northern States of Malaysia were involved in the study. The completed questionnaires were analysed to measure the variables of the study consisted of selected socio-demographic, travel behaviour and expenditure patterns. This study found the expenditure patterns of the young travellers vary with regards to the purchase of tourism products. In addition, the results of the study also portrayed the differences of selected travel-related characteristics of young travellers in relation to the purpose of travel. Thus, this study may provide information which will help tourism marketers to develop marketing tools to satisfy and fulfill those young tourists' needs and understand certain reasons behind their spending patterns.
\end{abstract}

Keywords: young traveller, travel behaviour, expenditure pattern, domestic tourism

\section{Introduction}

Youth travel is one of the fastest growing and most dynamic market of the global tourism sector. The World Tourism Organization (UNWTO) estimates that approximately 20 per cent of all international tourist arrivals in 2010 were young people. In that particular year, young travellers generate 165 billion USD towards global tourism receipts, affirming their financial value to the global tourism industry and local economies (United Nations World Tourism Organisation, 2011). Likewise, the World Youth and Student Travel Conference (WYSTC) identified that the young traveller market is worth about US\$136 billion (Simpson, 2010). In addition, young travellers have a higher lifetime value compare to other travel segment such as senior travellers. According to the UNWTO, based on youth and student travel market survey 2011, young travellers often spend more than other tourists and are likely to return and give more value to the destination over their lifetime. Furthermore, as the chances of getting higher education and exposure to the world, young travellers have penetrated and played an important role in the tourism market.

Malaysian young travellers are raised in an environment with a wide and increasing range of travel opportunities. As the low-cost carriers becoming the common travelling, transportation, the ease of information searching and tourism products, purchasing via the World Wide Web, travelling is at most accessible ever and thus increasing freedom to travel. Therefore, further study needs to be carried out to investigate their travel behaviour. Despite an increasing interest in the market size of young travellers, economic potential and their desire to travel, relatively little is known about their actual travel behaviour and expenditure patterns. Understanding the behaviour and expenditure patterns of Malaysian young travellers in tourism and hospitality is a matter of utmost importance for improving the sustainability of the tourism industry.

The market segment of young travelers, especially in Western countries is generally studied by researchers (Carr, 2001; 2005; Hesse \& Tutenges, 2011; Xu, Morgan, \& Song, 2009). UNWTO (2008) predicted that the main source of the forecast growth in travel demand will be the young, affluent middle class that is emerging - from 175 million people in 2008 to around 500 million by 2025. In relation to that, population statistics from 
Department of Statistics, Malaysia shows that there are 28.25 million of young travelers in Malaysia as in 2010. It has raised questions on the worthiness of carrying out a study of the travelling patterns of Malaysian young travelers.

Young travellers, though restricted by relatively low levels of disposable income, they commonly have high interests and leisure time in exploring new destinations. A convenient and inexpensive short-haul destination attracts younger and less affluent travellers (Jang, Bai, Hong, \& O'Leary, 2004). In addition, young travellers have high expectation regarding the importance of value for money though they have their financial resources available for travelling (Glover, 2010). They are willing to pay a premium price for it if they believe that the product, services or experience is worth it. This study will investigate the young traveller behaviour and expenditure patterns for this market group.

In terms of tourist spending, a recent report of tourism in Malaysia showed that even though Malaysia has the highest tourist arrival in the Southeast Asia region in 2012, the total revenue for tourism was less than Thailand and Singapore which have fewer tourist arrivals (The Star, 2013). That was in the case of international tourists. For domestic tourists, however, it was found that they are more active as compared to their international counterparts (Carr, 2002). This is due to the fact that those tourists who travelled the furthest to the holiday destination were likely to exhibit the 'allocentric' behaviour, while those travelling a relatively short distance behaved in a 'psychocentric' manner (Debbage, 1991). An 'allocentric' tourist may be defined as an inquisitive and curious individual, who is self-confident and adventurous, which is the opposite of a psycho-centric tourist (Hoxter \& Lester, 1988). Furthermore, it was suggested that the differences may have been a result of the greater ability of domestic tourists to become involved with the host population because of the lack of any language barriers, and the relative familiarity of their vacation surroundings, as compared to those of the foreign travellers (Laing, 1987). More importantly, Krippendorf (1987), who states, "having arrived at the scene of their dreams, many tourists behave in much the same way as they do at home"'(p. 31) Therefore, the current study is motivated to explore the Malaysian young travellers' travel behaviour when travelling to a domestic holiday destination. Furthermore, this study focused on domestic tourists' is rather different from other studies that concentrated more on international ones. The differences may be manifested through the way they spend, as well as the use of leisure time and space during their entire holiday. Indeed, these aspects of behaviour are the major focus of the current study.

\section{Objectives of the Study}

The main purpose of this study was to understand the Malaysian young travellers' behaviour and their expenditure patterns. Specifically, this study aimed to provide the meaningful perspectives to answer the following research objectives:

1) To develop a demographic profile of young Malaysians who have travelled within Malaysia in the past 12 months.

2) To identify the domestic travel behaviour among young Malaysians.

3) To determine the travel expenditure patterns among young Malaysians during their domestic travel.

4) To explore the young travellers' domestic travel behaviour and their spending patterns in relation to their purpose of travel.

\section{Literature Review}

Today, tourism is one of the world's largest industries. It is consisted of many segments such as transportation, accommodations, food and beverage services, shopping and activities for tourists. Each of these products and services is the key of an economic generator for the community specifically and the nation generally. Therefore, tourism is also considered as the sum total of tourist expenditures within the borders of a nation or a political subdivision or a transportation-centered economic area of contiguous states or nations (Goeldner \& Ritchie, 2006).

Advances in technology, communication and transportation are enhancing people's mobility and travel opportunity. It is no doubt that the travel and tourism expenditure continue to hike even during world economic recession. Hence, meeting the demands of domestic and international travellers by providing tourism-related goods and services became an attractive form of economic development in a nation (Cook, Yale, \& Marqua, 2006). It is imperative for the stakeholders of tourism and hospitality industry to understand the tourists' travelling behaviour of different segmentation. The analysis of travel behaviour and expenditure patterns will definitely contribute to more adequate and effective tourism marketing and management. 


\subsection{Young Traveller}

Taiyab (2005) defined the 'young' tourism market as travellers between 16 to 25 years old, who take a travel involving at least one night's stay. However, countries such as Canada has expanded this definition to include young adults between 26 to 30 years old. Meanwhile, the Student and Youth Travel Association of North America (SYTA) has also expanded the WTO's definition of youths to include those under 16 years of age, which makes the youth travellers are those between 16-35 years old (Carr, 2002).

In relation to this, as the chances of getting tertiary education are higher, most of the young travellers are students. This is agreed by Sellars (1998) that more are going on to higher education. Reisinger and Mavondo (2002) found that a growing proportion of young people now continue their education beyond the age of 25. Today's young generation enjoys travelling more than any generation before. The increasing purchasing power and spending behaviour of young people has made this demographic an attractive target for different industries. It was estimated that $20 \%$ of the 940 million tourists travelling the world in 2010 were young people (UNWTO, 2011). By 2020, there will be around 300 million international youth trips per year, which represent a $59 \%$ growth in 10 years. According to the UNWTO report, the average youth traveller spends a total of $\$ 2600$ per trip as compared to the average international tourist spends an average of $\$ 950$ (UNWTO, 2011). This indicates that youth travel is one of the fastest growing markets in the tourism sector. The youth, especially the student segment, though deemed as more price-sensitive yet they have ample time to travel (Grigolon, Kemperman \& Timmermans, 2012). In addition, Huang and Petrick (2010) stated that young travellers aged between 18 and 25 years are expected to be very influential.

According to Swarbrooke and Horner (2001), young people would rather not to take a holiday with their parents. This could take the form of an educational travel organised by schools, an organised children's camp like BUNAC or Camp America, an activity-based travel such as a PGL canoeing holiday in the UK or a farm-based vacation, for example, the 'Gîtes d' Enfants' in France and a single-sex group holiday with a group of friends. Report by Clarke (1992) showed that the inclusive tour package by the tour operator in the United Kingdom (UK) was all tied to the youth characteristics. Furthermore, the influence of Dance Music on the UK youth tourism market has caused the majority of the main packaged youth tour brochures are a Dance Music oriented (Sellars, 1998). However, findings from Chadee and Cutler (1996) showed that $51 \%$ of respondents (students) planned their travels without a travel agent.

\subsection{Campaign to Promote Domestic Tourism to Young Travellers}

'Cuti-Cuti Malaysia'(Malaysians go for holidays) is the campaign launched to promote domestic tourism among Malaysians. Domestic tourism involves residents of a country travelling within the borders of that country. For example, in the contexts of Malaysia, a person from Kuala Lumpur going for a holiday to Penang is a domestic tourist. The 'Cuti-Cuti Malaysia' Campaign was first introduced in the 11th of September 1999 to stimulate the growth of the number of domestic tourists in our country. The main objective of this campaign is to encourage the locals to plan their vacation properly and this campaign was targeted to reverse the view of locals that vacationing is something unnecessary and a waste of time and money. Other than that, this campaign is aimed at changing the 'balik kampung' (back to hometown) tradition into a tourism activity. This campaign was later rebranded to 'Zoom! Malaysia' on 14th May 2008 and finally changed to 'Cuti-Cuti 1Malaysia' Campaign, in line with the 1Malaysia concept introduced by The Right Hon. Prime Minister, Dato' Sri Haji Mohd. Najib bin Tun Haji Abdul Razak. (Musa Yusof, 2014). According to Musa Yusof (2014), the director of the domestic marketing division, Tourism Malaysia, the destinations that we expect to be popular among domestic tourists are divided into a few segments: eco-travel; culture and heritage; beaches and islands; and highlands - all of these destinations are promoted through 'Cuti-Cuti 1Malaysia' packages.

In promoting this campaign, the government issued a few directives that contribute towards the success of this campaign such as the provision of additional leave on the first and the third Saturday of every month to all public sector employees. The launch of the low-cost airline, Air Asia, on the December $1^{\text {st }}, 2001$ also helped in boosting the domestic tourism industry. The peak of the growth of the domestic tourism industry was when the government declared five working days a week starting from July $1^{\text {st }}, 2005$.

Besides that, the Youth Tourism Fair was organized by the Malaysian Youth Hostel Association in collaboration with the Ministry of Tourism during the Millions of Youth Gathering event on year 2011 and 2012. With the theme "Cuti-Cuti 1 Malaysia for 1 Malaysia Youth", affordable domestic travel packages were offered to young Malaysians. Also, the Student Tourism Programme (3Ps) was officially launched on February $24^{\text {th }}, 2001$ by the Minister of Culture, Arts and Tourism and the Minister of Education in order to encourage students to travel within Malaysia from a young age. Besides promoting domestic tourism, it is to motivate students spending their 
time wisely by exploring the historical, cultural and natural sites of Malaysia. Among the activities implemented are a Student Tourism Club, 3Ps Seminar as well as State and National Student Tourism Quiz (Ministry of Tourism Malaysia, 2011). Emphasis has been given for young Malaysians as their high potential in travelling can be predicted.

\subsection{Tourist Behaviour and Expenditure Patterns}

The study of tourist behaviour is the study of why people purchase certain tourism products, and how they make their decision (Schiffman \& Kanuk, 2007). Tourist behaviour research has focused on motivations, typologies, destination choice and the decision process (Hudson, 1999). Purchase of a holiday is generally involving a large spends. Therefore, factors such as internal and external motivations as well as other determinants which influence the purchase of tourism products must be studied thoroughly. Wang (2014) addresses that the motivations for travelling can be clustered into three groups, namely, psychological, cultural and economic. However, these motivations are commonly affected by the external environment such as social, economic and political factors. Thus, in order to study the travel patterns of youth, an in-depth understanding of tourist behaviour is vital for more effective and successful marketing activities. This is due to the fact that travel related decision is multi-faceted.

Disposable income is the major funding for travelling. Hence, Wang (2014) agreed that tourism participation restricted by budget constraint. However, young travellers get their travel fund from personal saving, student loan or scholarship, parents, as well as boyfriend or girlfriend or spouse (Carr, 2005). The study by Heung and Leong (2006) found that $43.6 \%$ of the university students have a travel budget of more than HK\$10, 000. Wang (2014) pointed out that Asians have higher saving behaviour than the Europeans. Hence, it is not doubtful when young people fund their travel from personal saving. Furthermore, strong economic conditions allow parents to fund their children's lifestyle. Likewise, same situation for those who have a partner or spouse with high income. The study of Xu et al. (2009) found that Chinese students' source of funding is from their parents while British students' funded their own trip. Besides that, younger travellers prefer using credit cards (Euromonitor, 2011). This is due to the fact that it is convenient and rewarding with advantages such as reward points, frequent flyer miles and cash back. The increased availability of credit facilities allows young Malaysians to travel around the world. Therefore, it is essential to assess their funding to fully understand their travel expenditure patterns. The growth of travelling interests among young Malaysians has drawn attention of researchers and marketers in understanding the determinants which influence their expenditure. The many ways of shopping for tourism products, purchasing methods, usage of different intermediaries and payment methods (Lawson, Thyne, Young \& Juric, 1999) of young travelers are worthy of investigation. Tourism expenditure is defined as "the total consumption expenditure made by a visitor on behalf of a visitor for and during his/her travel and stay at destination" (United Nations World Tourism Organization, 1994). Therefore, expenditure on different tourism products helps describing the size of each market in economic terms. Besides that, the identification of attributes that influence travel expenditure characteristics among young travellers can be achieved. According to Wang (2014), a travelers' decision on the amount to spend on a travel is the main factor that determines the tourism expenditure. Expenditure pattern is the expenses allocated on tourism products (Jang et al., 2004). In this study, the amount of money spent and the preference of purchasing tourism products such as transportation, accommodation, food and beverage, gifts and souvenirs as well as entertainment and recreation during a vacation are measured.

Transportation, accommodation, food and beverage establishment and activities are among the basic yet essential elements in a vacation. Preference of accommodation (Kim \& Jogaratnam, 2003), mode of transportation (Kim \& Jogaratnam, 2003), food and beverage (Kim \& Jogaratnam, 2003), activities (Kim \& Jogaratnam, 2003) as well as souvenirs (Swanson \& Horridge, 2006) has been studied in recent years. In addition to that, Reisinger and Mavodono (2004) agreed that personality and travel motivation is significantly related to activity preference. Lawson et al. (1999) was profiling the respondents into six cluster solutions (such as outdoor adventurers, sports devotees, fun-loving holidaymakers, education seekers, special family occasions as well as family holidays) to have a clearer appreciation of the different motives and attitudes differentiating between segments. The results were statistically significant when related to the behavioural variables in data that includes activities carried out on holiday, accommodation and transport choices, information search, booking options and payment methods. Due to the youth segment is more price sensitive, the main influence for their vacation decision is the cost of a travel (Grigolon et al., 2012).

The travel purpose among travellers such as visit friends and relatives (VFR) and business purposes have been widely studied by researchers. The nature of the trip will be varied according to the travelling purpose (Peerapatdit, 2004). For instance, VFR travellers spend less on accommodation because they have the tendencies 
of staying with friends or relatives in the tourist destination. Heung and Leong (2006) found that 'Experiencing new and different style' and 'Take it easy and relax' are the main purpose for travelling. In the meanwhile, the study comparing Chinese and British students by Xu et al. (2009) found that there are significant differences in attitudes towards travel. For example, Chinese students demonstrated that their trip is more educational purposes while British students' purpose of travel is more about having fun. This study contributes to the literature by examining the expenditure patterns of different travel purposes, which are travelling for leisure, travel for shopping, travel for visiting a theme park, travel for sightseeing, travel to visit historical/cultural destination, travel for sport/recreation and travel to visit friends/relatives.

In brief, the major gaps in the body of knowledge regarding tourist behaviour would be a great challenge to researchers. The subject of tourist behaviour and its ever changing quality are relevant to all participants in the tourism industry including academicians, marketers and policy makers. Hence, more research shall be conducted to fulfil the underdeveloped area of the study of tourist behaviour.

\section{Research Methods}

\subsection{Sample}

For the purpose of this study, population includes Malaysian young travellers aged between 21 to 35 years old. The focus of this study is to gather information from Malaysian young travelers from the northern region, which are Perlis, Kedah and Pulau Pinang. These destinations have been selected for various reasons. For instance, most of these destinations are among the most famous tourist destination in Malaysia (Oppermann, 1992) and offering different types of travel activities. Therefore, the number of tourists at these destinations can be expected to be relatively higher. University students from Universiti Utara Malaysia, Polytechnic Perlis and Sunway College, Penang were selected randomly to participate in this study. Respondents of the study include those who have travelled domestically in the previous 12 months from the day they participate in this study.

\subsection{Research Instrument}

The questionnaire was developed by adapting standard measured from various sources. The questionnaire consists of three sections. In Section A aimed to gather the socio-demographic background of each respondent. There were six questions regarding the sociodemographic profiles of respondents such as gender, age, ethnicity, education level, year of study, and source of income. Section B of the questionnaire consisted of questions related to the respondents' travel behavior. Section $\mathrm{C}$ includes questions regarding the type of travel and expenditure pattern that can be divided into seven sub-section, type of travel such as: leisure, shopping, visiting theme park, sightseeing, visiting historical/cultural destination, sport/recreation and visiting friends and relatives.

The questionnaire was prepared in Malay (Malay national language) hence translation processes of selected sources which originally in English were performed via back translation (Brislin, 1971). Then, we conducted a pilot test on the designed questionnaire to 100 respondents to evaluate reliability of the questionnaire. The results of this pilot test show that the measured reliability based on Cronbach's Alpha is adequate. Thus, such findings allow us to use the translated questionnaire for actual study.

\subsection{Data Collection}

A quantitative approach by using self-completed questionnaires were administered by two trained research assistants to collect data. The questionnaires were distributed between November 2012 to January 2013. A total of 800 questionnaires were distributed to the respondents. The respondents were asked to complete a survey questionnaire. The respondents were informed concerning the purpose of the study and general instructions were provided and help was offered when needed. The responses were confidential.

From the total 800 distributed questionnaire, 685 questionnaires were returned by the respondents, 42 survey questionnaires were either incomplete or did not meet the criteria for each section of the questionnaire, which resulted in a total of 643 usable questionnaires to be analysed for this study.

\section{Results}

\subsection{Sosiodemographic Data of Respondents}

The demographic data of the respondents are presented in Table 1, according to their gender, age, ethnicity, education level, year of study, and source of income. Females represented $68.7 \%$ of the respondents and males represented $31.3 \%$. The majority of respondents were age group between 19-21 years of age (56.3\%), 22-24 years of age (39.8\%), 25-27 years of age (3.4\%), while $28-30$ years of age represented only $0.3 \%$ and 31 years of age and above group represented $0.2 \%$ of total respondents. In terms of ethnicity, $52.9 \%$ of the respondents were Malays, $37.2 \%$ were Chinese, $7.2 \%$ were Indians, and only $2.8 \%$ representation of other ethnic groups of the 
total respondents. The majority of the respondents $(85.7 \%)$ pursuing their bachelor degree, $12.9 \%$ pursuing other academic qualifications such as diploma and certificate, and only $1.4 \%$ study at postgraduate degree level, and $98.3 \%$ of the respondents were in year 1 to year 4 of their tertiary education, while only $1.7 \%$ were in more than year 4. In terms of source of income, the majority of the respondents $(82.1 \%)$ obtained their source of income from PTPTN loan, $8.1 \%$ relied on the family, $5.8 \%$ reported income from scholarship, and $4 \%$ of the respondents reported obtained from another source of income.

Table 1. Demographic profile of respondents

\begin{tabular}{llll}
\hline Characteristic & & Frequency $(\mathbf{N = 6 4 3 )}$ & Percentage $\mathbf{~ \% ) ~}$ \\
\hline Gender & Male & 201 & 31.3 \\
Age (year) & Female & 442 & 68.7 \\
& $19-21$ & 362 & 56.3 \\
& $22-24$ & 256 & 39.8 \\
& $25-27$ & 22 & 3.4 \\
Ethnic Group & $28-30$ & 2 & .3 \\
& 31 and above & 1 & .2 \\
& Malay & 340 & 52.9 \\
Education & Chinese & 239 & 37.2 \\
& Indian & 46 & 7.2 \\
Year of study & Other & 18 & 2.8 \\
& Post Graduate & 9 & 1.4 \\
& Bachelor & 551 & 85.7 \\
& Other & 83 & 12.9 \\
& Year 1 & 176 & 27.4 \\
& Year 2 & 208 & 32.3 \\
Source of Income & Year 3 & 181 & 28.1 \\
& Year 4 & 67 & 10.4 \\
& Other & 11 & 1.7 \\
& PTPTN & 527 & 82.1 \\
& Scholarship & 37 & 5.8 \\
& Family & 52 & 8.1 \\
& Other & 26 & 4.0 \\
\hline
\end{tabular}

\subsection{Travel Behaviour and Expenditure Patterns}

Table 2 and Table 3 summarizes the results gathered from the survey pertaining to respondents' travel behaviour and expenditure patterns. The results indicate that the majority of students $(54.9 \%)$ chose to travel during their semester breaks holidays. However, some of them preferred to travel during weekends and public holidays for the purpose of leisure, shopping, sightseeing, visiting historical and cultural sites, sport and recreation, visiting friend and relatives, and theme parks. A total of 493 (76.7\%) out of 643 respondents reported they travelled for leisure purpose in the previous 12 months. The majority of respondents $(50.1 \%)$ out of 493 reported spending two nights at the destination visited and most of them (57.2\%) reported that they stayed in a hotel. In terms of spending, a majority of $44.2 \%$ of respondents reported average expenditure between RM201 and RM400, where most of their spending was on food and beverage (89\%). Meanwhile, 371 respondents reported that they have travelled for shopping in the previous 12 months, where the hotel was their main choice of accommodation (49.3\%). As compared with those who travelled for leisure, the majority of those who travelled for shopping stayed only one night (48.3\%). The majority of this group (44.8\%) spent between RM201 and RM400 while they were on their travel and surprisingly, spending on food and beverage was ranked the highest $(84.1 \%)$ while money spent for shopping was ranked second (83.6\%). A total of $301(46.8 \%)$ out of 643 respondents reported they travelled for sightseeing in the previous 12 months. Most of the respondents (46.5\%) reported spending one night at the destination visited with the hotel was the main choice of accommodation (42.2\%). For this purpose of travel, most of them (a total of 53.2\%) spent between RM101-RM300 where food and beverage was found to be the main reason of their spending.

For those who reported that they travelled to visit historical and cultural destination, hotel was still found to be the main selection of them (37.6\%), which was followed by those who stayed in a friends' or relatives' house. About $39.7 \%$ of respondents reported average expenditure between RM51 and RM200 while $37.6 \%$ reported 
between RM201 and RM400 with $80.8 \%$ of them ranked highest expenditure on food and beverage, which was followed by $47.6 \%$ and $46.3 \%$ spent on shopping and souvenirs respectively. The results also indicate that a total of $200(31.1 \%)$ out of 643 respondents reported they travelled for sport and recreation in the past 12 months. For this purpose of travel, three different modes of accommodation were found to be their major selections, where $25.5 \%$ out of 200 reported they stayed in the hotel, $23.5 \%$ chose to stay in the relative's or friend's house, and $27.5 \%$ reported stayed in chalet or resort. The majority of them stayed for two nights (44.5\%) when travelling for sports and recreation. Those who were involved in this type of travel seemed to have spent more where $45.5 \%$ of respondents reported their average expenditure between RM201 and RM400 while only 36\% reported between RM51 and RM200. Apart from their expenditure on accommodation and transportation, $82 \%$ of them reported that food and beverage is the major factor that they spent most, and as expected, $61.5 \%$ reported spending on entertainment and recreation.

Table 2. Travel behaviour and expenditure patterns

\begin{tabular}{|c|c|c|c|c|c|c|c|c|c|c|c|c|c|c|}
\hline \multirow[t]{2}{*}{ Purpose of Travel } & \multicolumn{2}{|c|}{$\begin{array}{l}\text { Leisure } \\
(N=493)\end{array}$} & \multicolumn{2}{|c|}{$\begin{array}{l}\text { Shopping } \\
(N=371)\end{array}$} & \multicolumn{2}{|c|}{$\begin{array}{l}\text { Sightseeing } \\
(N=301)\end{array}$} & \multicolumn{2}{|c|}{$\begin{array}{l}\text { Visiting Historical } \\
\& \text { Cultural } \\
\text { Destinations } \\
(N=229)\end{array}$} & \multicolumn{2}{|c|}{$\begin{array}{c}\text { Sports \& } \\
\text { Recreation } \\
(N=200)\end{array}$} & \multicolumn{2}{|c|}{$\begin{array}{c}\text { Visiting } \\
\text { Friends \& } \\
\text { Relatives } \\
(N=471)\end{array}$} & \multicolumn{2}{|c|}{$\begin{array}{l}\text { Theme } \\
\text { Park } \\
(N=282)\end{array}$} \\
\hline & $N$ & $\%$ & $N$ & $\%$ & $N$ & $\%$ & $N$ & $\%$ & $N$ & $\%$ & $N$ & $\%$ & $N$ & $\%$ \\
\hline \multicolumn{15}{|l|}{ Duration of stay } \\
\hline One night & 95 & 19.3 & 179 & 48.3 & 140 & 46.5 & 109 & 47.6 & 59 & 29.5 & 108 & 22.9 & 143 & 50.7 \\
\hline Two nights & 247 & 50.1 & 122 & 32.9 & 101 & 33.6 & 76 & 33.2 & 89 & 44.5 & 166 & 35.2 & 98 & 34.8 \\
\hline Three nights & 111 & 22.5 & 50 & 13.5 & 43 & 14.3 & 31 & 13.5 & 40 & 20.0 & 104 & 22.1 & 32 & 11.3 \\
\hline Four nights or more & 40 & 8.1 & 20 & 5.4 & 17 & 5.6 & 13 & 5.7 & 12 & 6.0 & 93 & 19.8 & 9 & 3.2 \\
\hline \multicolumn{15}{|l|}{ Place to stay } \\
\hline Hotel & 282 & 57.2 & 183 & 49.3 & 127 & 42.2 & 86 & 37.6 & 51 & 25.5 & 56 & 11.9 & 150 & 53.2 \\
\hline Chalet/Resort & 77 & 15.6 & 33 & 8.9 & 52 & 17.3 & 32 & 14.0 & 55 & 27.5 & 9 & 1.9 & 44 & 15.6 \\
\hline Friend's/Relative's house & 93 & 18.9 & 127 & 34.2 & 93 & 30.9 & 77 & 33.6 & 47 & 23.5 & 390 & 82.8 & 64 & 22.7 \\
\hline Homestay & 38 & 7.7 & 22 & 5.9 & 19 & 6.3 & 20 & 8.7 & 18 & 9.0 & 14 & 3.0 & 18 & 6.4 \\
\hline Other & 3 & 0.6 & 6 & 1.6 & 10 & 3.3 & 14 & 6.1 & 29 & 14.5 & 2 & .4 & 6 & 2.1 \\
\hline \multicolumn{15}{|l|}{ Average Expenditure } \\
\hline Below RM50 & 5 & 1.0 & 2 & .5 & 12 & 4.0 & 14 & 6.1 & 12 & 6.0 & 51 & 10.8 & 7 & 2.5 \\
\hline RM51 - RM100 & 29 & 5.9 & 32 & 8.6 & 37 & 12.3 & 26 & 11.4 & 15 & 7.5 & 79 & 16.8 & 23 & 8.2 \\
\hline RM101 - RM200 & 79 & 16.0 & 67 & 18.1 & 76 & 25.3 & 65 & 28.4 & 57 & 28.5 & 138 & 29.3 & 56 & 19.9 \\
\hline RM201 - RM300 & 137 & 27.8 & 100 & 27.0 & 84 & 28.0 & 51 & 22.3 & 46 & 23.0 & 95 & 20.2 & 74 & 26.2 \\
\hline RM301 - RM400 & 81 & 16.4 & 66 & 17.8 & 37 & 12.3 & 35 & 15.3 & 45 & 22.5 & 46 & 9.8 & 47 & 16.7 \\
\hline RM401 - RM500 & 68 & 13.8 & 40 & 10.8 & 28 & 9.3 & 13 & 5.7 & 13 & 6.8 & 24 & 5.1 & 38 & 13.5 \\
\hline RM501 and above & 94 & 19.1 & 64 & 17.2 & 27 & 9.0 & 25 & 10.9 & 12 & 6.0 & 38 & 8.0 & 37 & 13.1 \\
\hline \multicolumn{15}{|l|}{ Time of travel } \\
\hline Semester break & 325 & 65.9 & 224 & 60.4 & 151 & 50.2 & 122 & 53.3 & 92 & 46.0 & 254 & 54.0 & 154 & 54.6 \\
\hline Weekdays & 27 & 5.5 & 19 & 5.1 & 19 & 6.3 & 13 & 5.7 & 17 & 8.5 & 25 & 5.3 & 17 & 6.0 \\
\hline Weekends & 39 & 7.9 & 74 & 20.0 & 56 & 18.6 & 48 & 21.0 & 52 & 26.0 & 87 & 18.5 & 44 & 15.6 \\
\hline Public holidays & 99 & 20.1 & 53 & 14.3 & 74 & 24.6 & 47 & 20.4 & 36 & 18.0 & 104 & 22.1 & 67 & 23.8 \\
\hline Other & 3 & .6 & 1 & .3 & 1 & .3 & 0 & 0 & 3 & 1.5 & 1 & .2 & 0 & 0 \\
\hline $\begin{array}{l}\text { Money spent apart fron } \\
\text { accommodation } \\
\text { transportation }\end{array}$ & & & & & & & & & & & & & & \\
\hline Shopping & 340 & 69.0 & 310 & 83.6 & 152 & 50.5 & 109 & 47.6 & 84 & 42.0 & 317 & 67.3 & 119 & 42.2 \\
\hline Food \& Beverage & 439 & 89.0 & 312 & 84.1 & 249 & 82.7 & 185 & 80.8 & 164 & 82.0 & 381 & 80.9 & 224 & 79.4 \\
\hline Souvenirs & 172 & 34.9 & 145 & 39.1 & 121 & 40.2 & 106 & 46.3 & 63 & 31.5 & 151 & 32.1 & 92 & 32.6 \\
\hline $\begin{array}{l}\text { Entertainment } \\
\text { Recreation }\end{array}$ & 250 & 50.7 & 168 & 45.3 & 243 & 47.5 & 70 & 30.6 & 123 & 61.5 & 230 & 35.8 & 162 & 57.5 \\
\hline Entrance fee \& Tickets & 153 & 31.0 & 67 & 18.1 & 87 & 30.0 & 90 & 39.3 & 56 & 28.0 & 59 & 12.5 & 148 & 52.5 \\
\hline Tours \& Visiting & 188 & 38.1 & 93 & 25.1 & 108 & 36.0 & 92 & 40.2 & 49 & 24.5 & 140 & 29.7 & 65 & 23.1 \\
\hline Other & 1 & 0.2 & 8 & 2.2 & 3 & 1.0 & 4 & 1.8 & 6 & 3.0 & 15 & 3.2 & 3 & 1.1 \\
\hline
\end{tabular}


As compared with those who travelled for sports and recreation, the majority of those who travelled to visit friends or relatives (471 respondents) reported spending two nights at the destination (35.2\%) and unsurprisingly, most of them (82.8\%) reported they stayed in the relative's or friend's house (Table 2). The amount of money spent was also found to be lower than other types of visits where most of them (46.1\%) spent only between RM51 to RM200. However, most of them (80.9\%) still rated food and beverage as they have spent the most, which was followed by shopping (67.3\%). Finally, the survey found that a total of $282(43.9 \%)$ out of 643 respondents reported they travel to visit a theme park in the past 12 months. About half of them (50.7\%) reported spending one night at the destination visited, and mostly stayed in a hotel (53.2\%). About $43 \%$ of respondents reported average expenditure during visiting theme park travels between RM201 and RM400. Apart from their expenditure on accommodation and transportation, 79.4\% ranked food and beverage to be on the top three most spent on this kind of travel, while $57.5 \%$ reported spending on entertainment and recreation, $52.5 \%$ reported on entrance fee and buying tickets.

Table 3. Summary of means percentage of travel behavior

\begin{tabular}{llllll}
\hline Duration of stay & $\mathbf{\%}$ & Place to stay & $\mathbf{\%}$ & Time of travel & $\mathbf{\%}$ \\
\hline One night & 37.8 & Hotel & 39.6 & Semester break & 54.9 \\
Two nights & 33.5 & Chalet/Resort & 14.4 & Weekdays & 6.1 \\
Three nights & 13.9 & Relative/Friend's house & 35.2 & Weekends & 18.2 \\
Four nights or more & 7.7 & Homestay & 6.7 & Public holidays & 20.4 \\
& & Other & 4.8 & Other & .4 \\
\hline Average expenditure & $\mathbf{\%}$ & Money spent & $\mathbf{\%}$ & \\
\hline Below RM50 & 4.4 & Shopping & 57.5 & \\
RM51 - RM100 & 10.1 & Food \& Beverage & 82.7 & \\
RM101 - RM200 & 23.6 & Souvenirs & 36.7 & \\
RM201 - RM300 & 24.9 & Entertainment \& Recreation & 47.0 & \\
RM301 - RM400 & 15.8 & Entrance fee \& Tickets & 30.2 & \\
RM401 - RM500 & 9.2 & Tours \& Visiting & 31.0 & \\
RM501 and above & 11.9 & Other & 1.8 & \\
\hline
\end{tabular}

\section{Discussion}

Youth travel market has been identified as one of the major contributors to the growth of the world tourism sector. The importance of understanding about their choice of travel and spending patterns is therefore undeniable. The main objective of this study is to explore the young travellers' behaviour and their spending patterns in relation to their travel purposes. This study has been conducted among higher education students, which are said to have their own income from various sources to fund their travel activities.

From the survey, it was found that most of the young travellers who participated in this study preferred to stay in hotels, which was followed by relatives and friend's house. Other than staying in hotels this result has been contributed by those who travelled for visiting friends and relative where most of them stayed at the friends' or relatives' house. This finding is in line with a study by Swarbrooke (2007) where young travellers will stay at the friend's or relative's house to save budget. An equal percentage of respondents were found to have stayed for one night or two nights during each travel. As expected, since respondents for this study are mainly students, the travelling time is during semester break, weekends and public holiday. This finding provides an insight to the tourism marketers about when to promote their travel packages, especially those tailored to the young traveller.

Empirical results showed that even though students have relatively low income, where they relied mainly on scholarship and student loans (PTPTN) to fund their travelling activities (as with Hsu \& Sung, 1997; Xu et al., 2009), and that they have high interest in travelling. This has also been proven by Jang et al. (2004). Results from the current study also found that, in terms of where they spent their money, young travellers spent most of their money on food and beverage and shopping. Results also showed that young travellers also spent a big 
fraction of their money on recreation and entertainment. As stated by UNWTO (2008), many countries have specified their marketing activities to attract young travellers' niche market (such as sports and adventure). This study proved that young travellers are actively involved in the tourism activities in Malaysia and thus, proved that there is a big potential in the youth travel market in Malaysia.

This study also found that young travellers spent less on souvenirs, entrance fees and tickets as well as tours and visiting. However, Glover (2010) suggested that young travelers are willing to pay a premium price if they believe that the product, services or experience is worth it while at the same time, they have high expectation regarding the importance of value for money though they have their financial resources available for travelling.

\section{Conclusion}

\subsection{Implications}

Based on the overall results of this study, young travellers have been found to be very important to the future of the tourism industry, as what has been suggested by UNWTO (2008). This highlighted the importance of understanding the young travelers' behavior and their expenditure patterns, especially the tourism marketers and policy makers. By understanding the needs, wants and desires of this group, the marketers as well as policy makers could tailor their product or even design, promotional campaigns that could attract more of these people to travel. In light of the intensifying competition from neighbour countries such as Thailand, Indonesia and Vietnam, which offers more fun and affordable travel experience, policy makers play an important role in attracting the uprising young traveler market. Grigolon et al. (2012) concluded that price variation influence youth's decision, especially university students', to take a vacation to any destination.

This paper combines travel purposes to analyze the domestic tourism expenditure among young travelers. It proposes a different dimension than the previous literature, which has suggested the different expenditure patterns on various tourism products. This finding is imperative to the promotion of tourism in own country. This study also supports further to the key aspects of destination development which should include youth budget accommodation, cultural routes, information services, web portals, tour packages and discount programmes (UNWTO, 2008). From the traveller behavioural perspectives, this could provide chances for youth, especially university students who do not have steady income to explore the country and broaden their mind. From the business perspectives, this could expand their business opportunity and directly contribute to creating job opportunities, promoting economic development and increasing gross domestic product (GDP) growth of the country.

This study has examined the portfolio of young Malaysians who have travelled within Malaysia in the past twelve months. It is crucial for the tourism industry to investigate how, when, why and where the young Malaysians to be more willing to spend on domestic tourism and their behaviour during the entire travel. Policy makers and travel industry marketers will benefit from the knowledge of their behaviour. Prayag and Hosany (2014) conclude that there is a common pattern of young travellers, that is, they portray the needs for strengthening self-knowledge and looking for personalized tourism activities or amenities. Hence, the information gathered from this study also can be used as guidelines in formulating promotional programmes to encourage more spending on various tourism products and services especially by the young Malaysian travellers market. However, their price sensitive nature has suggested that the strategy of offering low fares campaign would succeed in obtaining youth's continuous support (Grigolon et al., 2012).

The present study intends to strengthen the existing literature by providing knowledges as well as valid data on the travel behavious and expenditure patterns in domestic tourism of young Malaysians. This paper differs from the literature in its emphasis on exploring young Malaysians' domestic travel behaviour and their spending pattern in relation to their purpose of travel. This study is one of the few study conducted in Malaysia. Therefore, this study will serve as a base for future studies of different dimensions and perspectives.

In addition to that, the findings of this study support the idea that young Malaysians are keen on travelling within the country. The findings are crucial in justifying the needs for more researches to be carried out in this area of tourism and hospitality field. Also, the improvement of measurement tools to be applied in future research is expected in exploring wider reviews of the travel and expenditure behaviour among young Malaysians. Hence, this study has enhanced the literature by expanding the previous knowledge of travel behaviour among youth generally and young Malaysians specifically.

The results of this study provide empirical evidence that young travellers' spending patterns are particularly based on their different purposes of travel to a destination. Spending most of their travel funds on food and beverages, shopping as well as recreation has addressed their preference during travelling. This was the unknown 
previously, but the actual spending power and pattern of young Malaysians has now revealed. Though spending behaviour of travellers has been studied widely by researchers from all over the globe, young Malaysians' travel and spending patterns should not be ignored in the tourism context because it is predictable by their travelling purposes.

\subsection{Limitations and Future Research}

This study raised the question of why the young travellers were unwilling to spend more on particular products. Though most young travellers are adventurous and flexible in the matter of visiting new attractions, the monetary cost involved are taken into consideration before heading to the destination (Grigolon et al., 2012). This highlights a gap and future research should explore further into why this is so and how to encourage the young travellers to spend more on certain areas. Further studies shall include the mode of transportation to examine how it influences the domestic travel holiday planning process, including the destination choice and length of stay. The interactions between transportation mode, accommodation type, duration of the trip, travel party and travel destination could be explored despite the many other dimensions shall be chosen and analysed (Grigolon et al., 2012).

However, because of this study is confined to the data made available through questionnaires distributed among university students, the generalizability of the findings is somewhat limited to how students spent during travel. Likewise, Nusair et al. (2013) pointed out that the research results collected from university students cannot fully generalize though they represent the typical youth segmentation. It would be interesting to examine the expenditure patterns of young travellers from a wider scope of study such as those who have already started their career, which includes those who travelled overseas. Further studies could explore this into a wider context for the current study, backed up by the previous literatures have highlighted the importance of the young travellers to the tourism industry.

Since this paper had limited access data from official statistics regarding young Malaysians' travelling patterns, a repeat cross-section analysis shall be carried out annually to study the current and actual travelling trends among young Malaysians. Also, it is recommended that motivation theories such as push-pull framework, expectancy-value or goal directed behaviour (Prayag \& Hosany, 2014) shall be added to derive more interesting conclusions. Other than money and time issue, the demand for domestic tourism too is subject to travelers motivation and intention. This study establishes a general understanding of the travel behaviour and expenditure patterns among young Malaysian travellers. Overall, this study has shown the importance of young travellers to the Malaysian tourism industry and the importance of this tourist segment in undeniable for the growth of tourism industry in the future.

\section{Acknowledgements}

The authors would like to extend their appreciation to the Universiti Utara Malaysia and Research Innovation Management Centre for the financial support and who make this presentation possible.

\section{References}

Brislin, W. R. (1971). Back-translation for cross-cultural research. Journal of Cross-Cultural Psychology, 1(13), 185-216.

Carr, N. (2001). An exploratory study of gendered differences in young tourists' perception of danger within London. Tourism Management, 22, 565-570. http://dx.doi.org/10.1016/S0261-5177(01)00014-0

Carr, N. (2002). A comparative analysis of the behavior of domestic and international young tourists. Tourism Management, 23, 321-325. http://dx.doi.org/10.1016/S0261-5177(01)00089-9

Carr, N. (2005). Poverty, debt, and conspicuous consumption: University students' tourism experience. Tourism Management, 26, 797-806. http://dx.doi.org/10.1016/j.tourman.2004.06.014

Chadee, D. D., \& Cutler, J. (1996). Insights into international travel by students. Journal of Travel Research, 35(2), 75-80. http://dx.doi.org/10.1177/004728759603500213

Clarke, J. (1992). A marketing spotlight on the youth four S's' consumer. Tourism Management, 13(3), $321-326$. http://dx.doi.org/10.1177/004728759703600109

Cook, R. A., Yale, L. Y., \& Marqua, J. J. (2006). Tourism the business of travel. New Jersey: Pearson International Edition.

Cooper, S. (2007). Youth tourism-the travel industry's boom sector. WYSE Travel Confederation.

Debbage, K. (1991). Spatial behaviour in a Bahamian research. Annals of Tourism Research, 18(2), $251-268$. 
Department of Statistics Malaysia (n. d.). Domestic tourism survey. Retrieved from http://www.statistics.gov.my/ portal/images/stories/files/LatestReleases/findings/SUMMARY_FINDINGS_DTS2011.pdf

Euromonitor International. (2011, April). Euromonitor International: Industry Overview April 2011 Travel and Tourism - Malaysia. Retrieved from http://www.portal.euromonitor.com.eserv.uum.edu.my/Portal/Handlers/ accessPDF.ashx?c=73\PDF\\&f=F-175813-19716273.pdf\&code=qRyGHABUNxonliRu3EaowrWOrF8\%3d

Glover, P. (2010). Generation Y's future tourism demand: some opportunities and challenges. In P. Benckendorff, G. Moscardo, \& D. Pendergast (Eds.), Tourism and Generation $Y$ (pp. 155-163). UK: CABI Publishing.

Goeldner, C. R., \& Ritchie, J. R. B. (2006). Tourism: Principles, Practices, Philosophies. New Jersey: John Wiley \& Sons, Inc.

Grigolon, A. B., Kemperman, A. D. A. M., \& Timmermans, H. J. P. (2012). The influence of low-fare airlines on vacation choices of students: Results of a stated portfolio choice experiment. Tourism Management, 33, 1174-1184. http://dx.doi.org/ 10.1016/j.tourman.2011.11.013

Hesse, M., \& Tutenges, S. (2011). Young tourists visitings travel clubs and paying for sex. Tourism Management, 32, 869-874. http://dx.doi.org/10.1016/j.tourman.2010.08.002

Hoxter, A. L., \& Lester, D. (1988). Tourist behaviour and personality. Personality and Individual Differences, 9(1), 177-178. http://dx.doi.org/10.1016/0191-8869(88)90045-1

Hsu, C. H. C., \& Sung, S. (1997). Travel behaviours of international students at a Midwestern university. Journal of Travel Research, 36(1), 59-65. http://dx.doi.org/10.1177/004728759703600109

Huang, Y., \& Petrick, J. F. (2010). Generation Y's travel behaviours: a comparison with Baby Boomers and generation X. In P. Benckendorff, G. Moscardo, \& D. Pendergast (Eds.), Tourism and Generation Y (pp. 27-37). Oxfordshire: CAB International.

Hudson, S. (1999). Consumer behavior related to tourism. In A. Pizam, \& Y. Mansfeld (Eds.), Consumer behavior in travel and tourism (pp. 7-32). New York: The Haworth Hospitality Press.

It is time to get the tourists to spend more. (2013, July 28). Sunday. The Star, p. 2.

Jang, S. C., Bai, B., Hong, G. S., \& O’Leary, J. T. (2004). Understanding travel expenditure patterns: a study of Japanese pleasure travelers to the United States by income level. Tourism Management, 25, 331-341. http://dx.doi.org/10.1016/S0261-5177(03)00141-9

Kim, K., \& Jogaratnam, G. (2003). Activity preferences of Asian international and domestic American university students: an alternate basis for segmentation. Journal of Vacation Marketing, 9(3), 260-270. http://dx.doi.org/10.1177/135676670300900305

Krippendorf, J. (1987). The holiday makers: understanding the impact of leisure and travel. Oxford: Heinemann Professional Publishing.

Laing, A. N. (1987). The package holiday: participant, choice and behavior (Ph.D. Thesis). Hull University.

Lawson, R., Thyne, M., Young, T., \& Juric, B. (1999). Consumer behavior related to tourism. In A. Pizam, \& Y. Mansfeld (Eds.), Consumer behavior in travel and tourism (pp. 449-479). New York: The Haworth Hospitality Press.

Ministry of Tourism, Malaysia. (2011, January 10). Student tourism programme. Retrieved from http://www.motour.gov.my/en/ministrys-programme/tourism-programme/student-tourism-programme.html

Nusair, K. K., Bilgihan, A., Okumus, F., \& Cobanoglu, C. (2013). Generation Y travelers' commitment to online social networking websites. Tourism Management, 35, 13-22. http://dx.doi.org/10.1016/j.tourman. 2012.05.005

Oppermann, M. (1992). International tourist flow in Malaysia. Annals of Tourism Research, 19, 482-500. http://dx.doi.org/ 10.1016/0160-7383(92)90132-9

Peerapatdit, N. (2004). The impact of selected socio-demographic, travel-related and psychographic variables on the travel expenditures. Unpublished master's thesis. University of Central Florida, Orlando.

Prayag, G., \& Hosany, S. (2014). When Middle East meets West: Understanding the motives and perceptions of young tourists from United Arab Emirates. Tourism Management, 40, 35-45. http://dx.doi.org/10.1016/j.tourman.2013.05.003

Reisinger, Y., \& Mavonda, F. (2002). Determinants of youth travel markets' perceptions of tourism destinations. 
Tourism Analysis, 1(7), 55-66. http://dx.doi.org/10.3727/108354202129687688

Reisinger, Y., \& Mavonda, F. (2004). Exploring the relationships among psychographic factors in the female and male youth travel market. Tourism Review International, 8(2), 69-84. http://dx.doi.org/10.3727/154427204 2782156

Schiffman, L. G., \& Kanuk, L. L. (2007).Consumer behavior (9th ed.). New Jersey: Pearson Prentice Hall.

Sellars, A. (1998). The influence of dance music on the UK youth tourism market. Tourism Management, 19(6), 611-615. http://dx.doi.org/10.1016/S0261-5177(98)00000-4

Simpson, D. (2010). Youth matters: Why the youth travel market shouldn't be underestimated. Retrieved from http://www.cabi.org.eserv.uum.edu.my/leisuretourism/?fp=21142\&loadmodule=newsarticle\&page $=4060 \& \mathrm{~s}$ ite $=156$

Swanson, K. K., \& Horridge, P. E. (2006). Travel motivations as souvenirs purchase indicators. Tourism Management, 27, 671-683. http://dx.doi.org/10.1016/j.tourman.2005.03.001

Swarbrooke, J., \& Horner, S. (2001). Consumer behaviour in tourism. Oxford: Butterworth Heinemann.

Taiyab, M. M. (2005). The role and importance of youth tourism in the Malaysian tourism industry. Retrieved from http://fabserver.utm.my/download/ConferenceSemiar/YouthTourism2006PPKN01

United Nations (UN) Department for economic and social information and policy analysis and World Tourism Organization (WTO). (1994). Recommendations on tourism statistics. New York: United Nation.

United Nations World Tourism Organisation. (2008). Youth travels important for tourism industry's growth. Retrieved from http://www.victoo.com/youth-travel-important-for-tourism-industry-s-growth-says-unwto. html

United Nations World Tourism Organisation. (2011). The power of youth travel. Retrieved from http://www2.unwto.org/en/publication/am-reports-volume-2-power-youth-travel

Wang, Y. S. (2014). Effects of budgetary constraints on international tourism expenditures. Tourism Management, 41, 9-18. http://dx.doi.org/10.1016/j.tourman.2013.08.006

Xu, F., Morgan, M., \& Song, P. (2009). Students' travel behavior: A cross-cultural comparison of UK and China. International Journal of Tourism Research, 11, 255-268. http://dx.doi.org/ 10.1002/jtr.686

Yusof, M. (2014). Gaya Travel: Visit Malaysia Year 2014. Retrieved from http://www.gayatravel.com.my/ articles/musa-yusof-director-domestic-marketing-division-tourism-malaysia

\section{Copyrights}

Copyright for this article is retained by the author(s), with first publication rights granted to the journal.

This is an open-access article distributed under the terms and conditions of the Creative Commons Attribution license (http://creativecommons.org/licenses/by/3.0/). 